\title{
The Formula Study of Strength Index for Remolded Loess
}

\author{
Kangfeng Yuan a \\ (a, Key Lab of Highway Construction \& Maintenance Technology in Loess Region, Ministry of \\ PRC, b, Shanxi Key Laboratory of Highway Construction \& Maintenance Technology \\ in Loess Region,Shanxi Transportation Research Institute, Shanxi, Taiyuan 030006, China) \\ Transport, \\ ayuankangfeng@163.com
}

\begin{abstract}
At present, the research is not enough for the formula of water content and strength index in domestic.The paper aims how the change of water content influence strength index of remolded loess by consolidation drained triaxial shear test for the Linxian loess.The results showed that: The shear strength of loess decreases larger with the increasing of water content. The change of shear strength index $\mathrm{c}$ is obvious with the increasing water content. The change of shear strength index ${ }^{\varphi}$ is not obvious with the increasing water content.According to the formula of strength index, to predict the strength index for certain water content of the tests loess, have some theoretical significance for the relation research.
\end{abstract}

Key words : consolidation drained; remolded loess; water content; strength index; formula

\section{INTRODUCTION}

The strength of the loess is an important soil mechanics.A lot of engineering problem have associated with soil stability, such as bearing capacity of loess foundation, tunnel and slope. Many scholars have done a lot of work about the strength problem of soil. Wang Zhi-jie et al ${ }^{[1]}$ think the dry density has little effect on the dynamic shear modulu of remodeled loess under the condition of pre-shearing stress.Initial average prinicipal stress has some certain effect on the modulu.SHEN Chun-ni et $\mathrm{al}^{[2]}$ think that the cohesion of unsaturated soil has an exponent increase with the increasing of dry density; but the friction angle has little change with the increasing of dry density. The comparison of the test results with controlled suction and water content equaling constants is carried out. The shear strength formula including impact of water content is proposed, which can be for reference in engineering
application.The studies showed that: the remolded loess strength is influenced by conditions such as water content. The different conditions have distinct effects for the strength index of loess. However, for the strength characteristics of remolded loess, there is rare research on the formula of loess strength index [3]-[27]

With the help of consolidated drained triaxial tests to research the shear strength characteristics of remolded loess for different water content. Analysis the formula of loess strength index, to come up some conclusions. The study have some theoretical significance for the research of remolded loess strength index. And it will provide reference for the future research of remolded loess strength.

\section{THE LOESS OF TEST}

The loess of tests is taken from certain pit at the Linxian district, in a depth of $3 \mathrm{~m}$ below the surface, which is silty clay. And the loess samples have been whittled to length $30 \mathrm{~cm}$ $33 \mathrm{~cm}$ cube in the field. The natural water content of the loess was $7.3 \%$, through the burette method to configure the required water content for the sample.

\section{Test Instruments AND Test MethoD}

\section{A. Test Instruments}

The test instrument is the conventional triaxial shear apparatu which come from a 
Nanjing experimental instrument factory. The pressure will pass to the specimen with the help of the counterproductive of fixed beam.

\section{B. Test Method}

Prepare remolded triaxial loess specimen which water content are separate $7.5 \%, 9.5 \%$, $11.5 \%, 13.5 \%, 15.5 \%$ and the amount is also four.The confining pressure are separate 50 $\mathrm{kPa}, 100 \mathrm{kPa}, 200 \mathrm{kPa}, 400 \mathrm{kPa}$ for drained consolidated test. The specimen install before exert confining pressure, open the drain valve to consolidation, and start motor to cut after the end of consolidation. The final shutdown standard is the axial deformation which reach $12 \mathrm{~mm}$.

\section{Test RESUlts AND ANALYsis}

A. The law of shear strength changing with water content for remolded loess

According to formula 1:

$$
\tau=c+\sigma \tan \phi
$$

The law of remolded loess shear strength changing with water content is indicated in Fig .1toFig .5:

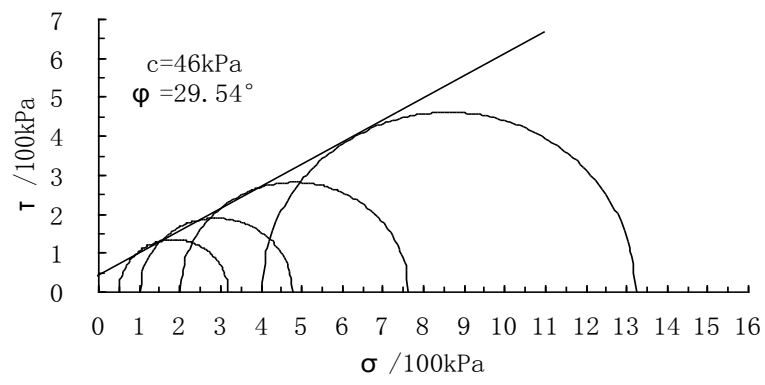

Figure 1. Shear strength lines for $\mathrm{w}=7.5 \%$

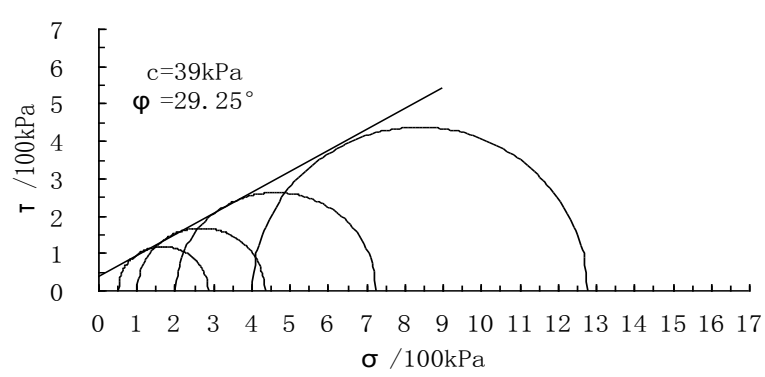

Figure 2. Shear strength lines for $\mathrm{w}=9.5 \%$

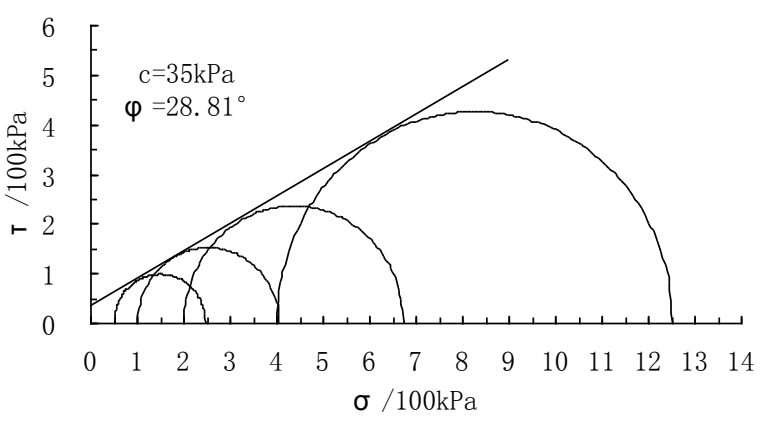

Figure 3. Shear strength lines for $\mathrm{w}=11.5 \%$

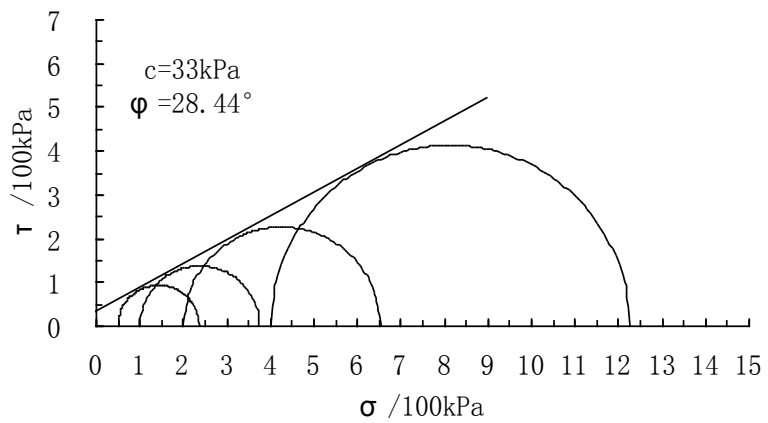

Figure 4. Shear strength lines for $w=13.5 \%$

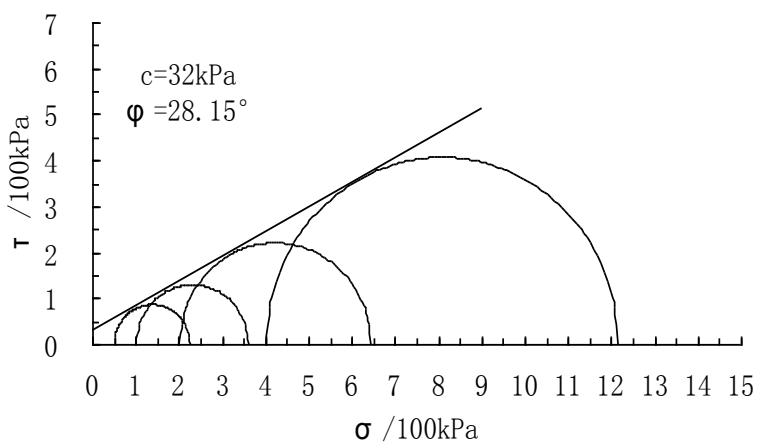

Figure 5. Shear strength lines for $\mathrm{w}=15.5 \%$

Fig .1 to Fig .5 show that the shear strength of loess decreases larger with the increasing of water content.

\section{B. The law of strength index changing with water content for remolded loess}

The law of remolded loess strength index under different water content is indicated inFig .6 to Fig .7: 


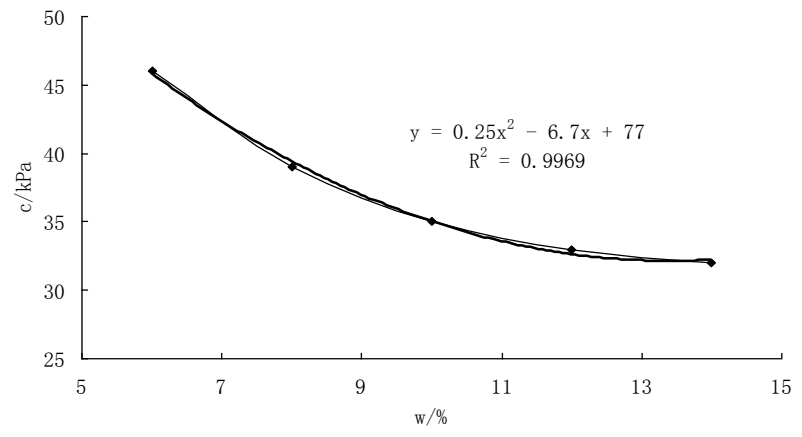

Figure 6. Strength index c for water content

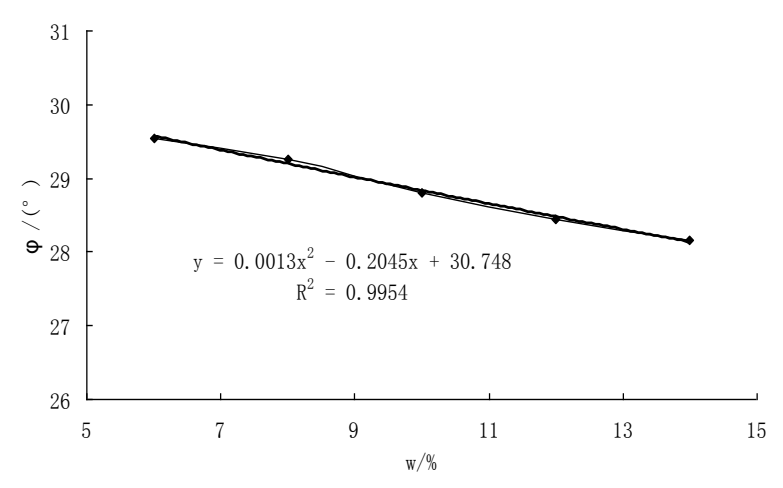

Figure 7. Strength index $\varphi_{\text {for water content }}$

Fig .6, Fig .7 show that the change of shear strength index $\mathrm{c}$ is obvious with the increasing water content. The change of shear strength index $\varphi$ is not obvious with the increasing water content.

According toFig .5, Fig .6, the relationship of strength index and water content can be converted to the following formula:

$$
\begin{gathered}
c=0.25 \omega^{2}-6.7 \omega+77 \\
\phi=0.0013 \omega^{2}-0.2045 \omega+30.748
\end{gathered}
$$

According to formula 2, formula 3, to predict the strength index for certain water content, have some theoretical significance for the relation research.

\section{Conclusions}

In this paper, conventional triaxial test apparatus is applied to study remolded loess strength index under water content. The main conclusions are as follows:

(1) The shear strength of loess decreases larger with the increasing of water content.

(2) The change of shear strength index $c$ is obvious with the increasing water content. The change of shear strength index $\varphi$ is not obvious with the increasing water content.

(3) According to the formula of strength index, to predict the strength index for certain water content of the tests loess, have some theoretical significance for the relation research.

\section{ACKNOWLEDGEMENTS}

The paper is Sponsored by the Research Project of Shanxi Provincial Communication Department [2012-1-3].

\section{REFERENCES}

[1] WANG Zhi-jie, LUO Ya-sheng, TAN Dong-yue,et al. Experimental Study on the Effects of Dry Density on Dynamic Properties of Remodeled Loess under Condition of Pre-shearing Stress [J].NORTHWESTERN SEISMOLOGICAL JOURNAL, 2011,33(4) : 349-353. (in Chinese)

[2] SHEN Chun-ni, FANG Xiang-wei,WANG He-wen,et al.Research on effects of suction,water content and dry density on shear strength of remolded unsaturated soils [J]. Rock and Soil Mechanics, 2009,30(5) : 1347-1351. (in Chinese)

[3] S.K.Vanapalli,D.G.Fredlund D.E.Pufahl and A.W.Clifton,Model for the Predicition of Shear Strength with respect to Soil Suction, Can.Geotech.J.Vol.33,1996.

[4] SONG Fei. The study on the stability and deformation mechanism of huazicun loess landslide [J].SHANXI SCIENCE \& TECHNOLOGY of COMMUNICATIONS, 2012,216(3) : 13-15. (in Chinese)

[5] LI Xu-hua.The Rational Slope Type Research on Loess High Slope [J].SHANXI SCIENCE \& TECHNOLOGY of COMMUNICATIONS, 2012,214(1):29-30. (in Chinese)

[6] Fredlund D G,Morgenstern N R.Stress state variables for unsaturated soils[J].Journal of the EngineeringDivision,ASCE, 1997,103(GT5):477-466

[7] WANG Li-zhong, ZHAO Zhi-yuan, LI Ling-ling.Non-linear elastic model considering soil structural damage[J]. Journal of Hydraulic Engineering, 2004, (1):83-89.(in Chinese)

[8] XIONG Chuan-xiang, GONG Xiao-nan. An updated elastoplastic damage model for structural soft-clays[J].Rock and Soil Mechanics, 2006, 27(3): 395 - 397.(in Chinese)

[9] SHEN Zhu-jiang, LIU En-long, CHEN Tie-lin. Generalized Stress-Strain Relationship of Binary Medium Model for Geological Materials[J]. Chinese Journal of Geotechnical Engineering, 2005,27(5):489-494.(in Chinese)

[10] Zhu Si-zhe,Liu Qian,Chang Ya-ping,et al.The principles and Applications Technology of Triaxial Tests[M].2003,China Electric Power Press. (in Chinese)

[11] Jennnigs J E.A revised effective stress law for use in the prediction of behavior about unsaturated soils[A].Poreeeding of Pore Pressure and Suction in soils[C], London, U.K., 1961, 26-30

[12] Artehsor G D.Relationship of moisture stress and effective stress function in unsaturated soils[A].Proeeeding of Pore Pressure and Suction in soils[C], London, U.K., 1961, 47-52

[13] Barden L.Pavlakis G.Air and water permeability of compacted unsaturated cohesive soil[J].Journal of Soil Society,1971, 23(3): 302-317

[14] J.K-M.Can and D.G.Fredlund,Shear Strength Characteristics of Two Saprolitic Soils from Hong Kong,Sino-Canadian Symposium on Unsaturated/Expansive Soils, Wuhan,June.1994. 
[15] Rohm S A,Vilar O M..Shear strength of unsaturated sandy soil[A].Proc.1st $\quad$ Int.Conf. Unsaturated Soils[C].Paris.[s.n.].1995,189-195.

[16] Bishop A W, Blight G E.Some aspects of effective srtess in suatrated and partly saturated soils[J].Geotechnique, 1963 , (13)3:177-196.

[17] Bishop A W, Donald I B.The experim ental sutdy of partly saturated soil in the triaxial apparatus[A].Proeeeding of 5th Intenrational Conference on Soil Mechnaics and Foundation Engineering[C],Paris, Franee, 1961, 1:13-21.

[18] Croney D,Coleman J D,Black W P M, The movement and distribution of water in soil in relation to highway design and performance[R].Highway Research Board,1958,Special Report No.40.

[19] Wood C C.Shear strength and volume change characteristics of compacted soil under conditions of plane strain[D].London: University of London, 1958.

[20] Shibata T, Karube D.Influence of the variation of the intermediate principal stress on the mechanical properties of normally consolidatedclays[C].// Proc of the 6th ICSMFE.Toronto 1 : Univ.of Toronto Press, 1965: 359-363.

[21] Fredlund D G, Xing A Q, Fredlund M D, et al. The relationship of the unsaturated soil shear strength to the soil-water characteristic curve[J]. Canadian Geotechnical Journal,1996,33(3):440-448.

[22] Ng C W W, Pang Y W. Influence of stress state on soil-water characteristics and slope stability[J]. Journal of Geotechnical and Geoenvironmental Engineering, 2000, 126(2):157-166.

[23] Kawaik, Karube, Kato S. The model of water retention curve considering effects of void ratio[C] / /Unsaturated Soils for Asia. Rotterdam: Balkema, 2000: 329-334.

[24] SHEN Zhu-jiang, CHEN Tie-lin. Breakage Mechanics of Geomaterial-Structure Types and Load Sharing[J]. Chinese Journal of Rock Mechanics and Engineering, 2004,23(13):2137-2142.(in Chinese)

[25] MIAO Lin-chang, CUI Ying, CHEN Ke-jun, et al.Tests on strength of unsaturated remolded expansive soils[J].Chinese Journal of Geotechnical Engineering, 2006,28(2): 274-276. (in Chinese)

[26] Li Zhi-qing, $\mathrm{Li}$ Tao, $\mathrm{Hu}$ Rui-lin, $\mathrm{Li}$ Xiong, $\mathrm{Li}$ Zhuang-ju.Methods for testing and predicting of Swcc in unsaturated soil mechanics. Journal of Enigineering Geology, 2007, 15( 5): 700 - 706. (in Chinese)

[27] ZHOU Jian, YANG Yong-xiang, LIU Yang. Numerical modeling of sand liquefaction behavior under cyclic loading[J]. Rock and Soil Mechanics, 2009, 30(4): 1083-1088. (in Chinese) 